\title{
Pengembangan Program Pencegahan dan Pengendalian Infeksi COVID-19 dalam Mempertahankan Status Kesehatan pada Tenaga Kesehatan di Rumah Sakit Kota Medan
}

\author{
Muhammad Taufik Daniel Hasibuan ${ }^{1, *}$, Harsudianto Silaen ${ }^{2}$ \\ ${ }^{1}$ STIKes Murni Teguh, Jl. Jawa No.2 Kelurahan Gang Buntu, Medan, Indonesia \\ ${ }^{2}$ STIKes Murni Teguh, Jl. Jawa No.2 Kelurahan Gang Buntu, Medan, Indonesia \\ 1'aniel.jibril@gmail.com*; ${ }^{2}$ antosilaen4@ gmail.com \\ * corresponding author
}

ARTICLE INFO

Article history

13-08-2021

$02-09-2021$

01-10-2021

Keywords

Infection Prevention and Control

Covid 19

Health

Health Workers

\section{ABSTRACT}

The COVID-19 infection prevention and control program in hospitals is an effort to provide guidance for health workers to stay healthy, safe, productive, and the community gets services that meet standards. Health workers who work in hospitals are very vulnerable to being exposed to COVID -19, so it is very important that health workers and policy makers understand the basic concepts of infectious diseases. The purpose of this study was to develop a program to prevent and control covid-19 infection in maintaining the health status of health workers at the Medan City Hospital. The type of research used is action research. The participants in this study were 14 people consisting of 2 parts, namely 1) Participants for qualitative data were taken from managerial such as medical services, nursing, medical records, infection prevention and control units, and the head of the room. 2) Participants for quantitative data are taken from health workers, namely nurses. Data collection in this study used various methods, namely individual interviews, observation, self-report, focus group discussions and several data collection tools, namely interview guides, focus group discussion guides, questionnaires, observation sheets, and supporting tools, namely voice recorders. The results of this study obtained outputs, namely standard operating procedures for the prevention and control of covid-19 infection, and from the results of health status checks on health workers from before and after the implementation of the COVID -19 infection prevention and control program, the results were before (PCR/Antigen: Negative). $71.43 \%$, Positive: 28.57\%; Vital sign normal: $85.71 \%$, Abnormal 14.29\%), and after (PCR/Antigen: Negative 85.71\%, Positive: 14.29\%; Vital sign normal: $100 \%$ ). This proves that there is an influence of the Covid-19 infection prevention and control program in maintaining the health status of health workers in hospitals. Suggestions to hospital leaders to continue to evaluate prevention and control programs for COVID-19 infection in accordance with developments and the situation at hand.

\section{Pendahuluan}

Program pencegahan dan pengendalian infeksi (PPI) covid-19 dirumah sakit merupakan upaya untuk memberikan panduan bagi petugas kesehatan agar tetap sehat, aman, produktif, dan masyarakat mendapatkan pelayanan yang sesuai standar [1]. Dalam upaya pencegahan dan pengendalian infeksi di fasilitas pelayanan kesehatan sangat penting bila petugas dan pengambil kebijakan memahami konsep dasar penyakit infeksi. Oleh karena itu sangat diperlukan pedoman pencegahan dan pengendalian infeksi di fasilitas pelayanan kesehatan agar terwujud pelayanan kesehatan yang bermutu dan dapat menjadi acuan bagi semua pihak yang terlibat dalam pelaksanaan pencegahan dan pengendalian infeksi di dalam fasilitas pelayanan kesehatan serta dapat melindungi masyarakat dan mewujudkan patient safety yang pada akhirnya akan berdampak pada efisiensi manajemen fasilitas pelayanan kesehatan dan peningkatan kualitas pelayanan [2].

Pada tanggal 30 Januari 2020, WHO menetapkan corona virus sebagai Public Health Emergency of International Concern (PHEIC)/ Kedaruratan Kesehatan Masyarakat Yang Meresahkan Dunia (KKMMD) [3]. Pada tanggal 2 Maret 2020, Indonesia telah melaporkan kasus 
covid-19 dan pada tanggal 11 Maret 2020 WHO menetapkan COVID-19 sebagai pandemi [4]. Peningkatan jumlah kasus berlangsung cukup cepat, dan menyebar ke berbagai negara dalam waktu singkat. Sampai dengan tanggal 9 Juli 2020, WHO melaporkan 1184226 kasus konfirmasi dengan 545.481 kematian di seluruh dunia (Case Fatality Rate/CFR 4,6\%). Kasus meningkat dan menyebar dengan cepat di seluruh wilayah Indonesia. Sampai dengan tanggal 9 Juli 2020 Kementerian Kesehatan melaporkan 70.736 kasus konfirmasi COVID-19 dengan 3.417 kasus meninggal (CFR 4,8\%), dan angka tersebut masih terjadi peningkatan setiap harinya [1].

Pengetahuan dan pemahaman dari tenaga kesehatan masih terbatas karena COVID-19 merupakan penyakit jenis baru yang masih berlanjut penularannya dan masih diteliti vaksinnya [5]. Tenaga kesehatanyang bertugas dirumah sakit sangat rentan terpapar oleh COVID-19. Pemberian pelatihan terkait pencegahan infeksi berkaitan dengan penurunan resiko terinfeksi covid-19 [6]. Tingginya resiko tenaga kesehatan yang terpapar atau terinfeksi covid-19 disebabkan oleh lamanya terpapar virus dan jumlah virus yang banyak sewaktu melakukan kontak dengan pasien [7]. Faktor terpaparnya tenaga kesehatan juga dipengaruhi oleh kurangnya pengetahuan terkait penggunaan alat pelindung diri (APD) yang benar, kelangkaan APD, dan pasien yang tidak jujur didalam memberikan informasi karena takut mendapatkan stigma negatif dari orang lain [8].

\section{Metode}

Jenis penelitian yang digunakan dalam penelitian ini adalah action research. Kegiatan dalam siklus action research melibatkan partisipasi aktif dari partisipan dalam merencanakan kegiatan, melaksanakan kegiatan, mengamati dan memantau kegiatan serta melakukan refleksi terhadap kegiatan yang telah dilaksanakan selama melakukan pengembangan program PPI. Penelitian dilakukan di Rumah Sakit Murni Teguh Kota Medan, dari April sampai September 2021. Partisipan dalam penelitian ini berjumlah 14 orang yang terdiri dari 2 bagian yaitu 1) Partisipan untuk data kualitatif diambil dari manajerial PPIseperti bidang pelayanan medis, bidang keperawatan, bidang rekam medis, unit bagian PPI, dan kepala ruangan. 2) Partisipan untuk data kuantitatif diambil dari tenaga kesehatan yaitu perawat pelaksana. Penentuan jumlah sampel diambil dengan cara purposive sampling.Pengumpulan data dalam penelitian ini menggunakan berbagai metode yaitu wawancara individu, observasi, self report, focus group discussion dan beberapa alat pengumpulan data yaitu panduan wawancara, panduan focus group discussion, kuisioner, lembar observasi, serta alat penunjang yaitu voice recorder.

\section{Hasil dan Diskusi}

\subsection{Karakteristik Demografi Partisipan}

Partisipan didalam penelitian ini terdiri dari dua kelompok yaitu kelompok tim manajerial PPI dan kelompok partisipan tenaga kesehatan. Jumlah partisipan tim manejerial PPI sebanyak 7 orang yang terdiri dari 1 orang kepala bidang pelayanan medis, 1 orang kepala bidang keperawatan, 1 orang kepala bidang rekam medis, 1 orang kepala unit bagian PPI, 3 orang kepala ruangan, dan partisipan tenaga kesehatan terdiri dari 7 orang perawat pelaksana.

Tabel 1. Data Demografi Partisipan Tim Manajerial PPI

\begin{tabular}{cccc}
\hline No & Karakteristik & Frekuensi & Persentase (\%) \\
\hline 1 & Usia & & \\
& 20-30 Tahun & 2 & 28.57 \\
& 31-40 Tahun & 2 & 28.57 \\
& $41-50$ Tahun & 3 & 42.86 \\
\hline 2 & Jenis Kelamin & & 14.28 \\
Laki - laki & 1 & 85.72 \\
\hline & Perempuan & 6 & 14.28 \\
& Pendidikan & 71.44 \\
D-3 & 1 & 14.28 \\
\hline 4 & S1- Profesi & 5 & 42.86 \\
S-2 & 1 & 57.14 \\
\hline
\end{tabular}




\begin{tabular}{llcc}
\multicolumn{4}{c}{ Tabel 2. Data Demografi Partisipan Tenaga Kesehatan } \\
\hline No & Karakteristik & Frekuensi & Persentase (\%) \\
\hline 1 & Usia & 3 & 42.86 \\
& 20 - 30 Tahun & 4 & 57.14 \\
& 31-40 Tahun & & \\
\hline 2 & Jenis Kelamin & 2 & 28.57 \\
& Laki - laki & 5 & 71.43 \\
& Perempuan & 3 & 42.86 \\
\hline 3 & Pendidikan & 4 & 57.14 \\
& D-3 & 4 & \\
& S1- Profesi & 2 & 28.57 \\
\hline 4 & Pengalaman Bekerja & 3 & 28.86 \\
& 1 sd 2 Tahun & 2 & \\
& 3 sd 4 Tahun & & \\
& $>$ 5 Tahun & &
\end{tabular}

\subsection{Proses pengembangan Program Pencegahan dan Pengendalian Infeksi Covid-19}

Proses pengembangan program pencegahan dan pengendalian infeksi covid-19 terdiri dari 2 tahap. Tahap pertama adalah reconnaissance, tahap ini menjelaskan mulai dari pendekatan kepada pihak-pihak yang berkepentingan di tempat penelitian sampai dengan mendapatkan masalah untuk diteliti. Tahap kedua menjelaskan tentang tahap siklus action research mulai dari tahap planning, action, dan observation serta reflection.

\subsubsection{Tahapan reconnaissance}

Tahap reconnaissance dilaksanakan peneliti sejak bulan Mei sampai dengan Juni 2021. Peneliti meminta izin dan melakukan pendekatan kepada pemilik Rumah Sakit dan pejabat struktural untuk mendapatkan izin agar terlaksananya kegiatan penelitian. Pengumpulan data awal yang dilakukan peneliti adalah dengan melakukan wawancara tentang program pencegahan dan pengendalian infeksi covid-19 kepada tim perumus PPI pada tahap reconnaissance dan self report tentang status kesehatan dari partisipan perawat.

Hasil pengumpulan data pada tahap reconnaissance dikelompokan ke dalam tiga bagian yaitu (1) Konteks studi yang menggambarkan setting tempat penelitian dan partisipan, (2) Perspektif tim manajerial PPI tentang program pencegahan dan pengendalian infeksi covid-19 di rumah sakit tersebut, dan (3) Pemeriksaan status kesehatan pada tenaga kesehatan terhadap infeksi covid-19 di Rumah Sakit. Berikut penjelasan dari hasil reconnaissance, yaitu:

\section{1) Setting tempat penelitian dan partisipan}

Penelitian dilakukan di wilayah kerja rumah sakit dan berfokus pada unit perawatan covid19. Rumah sakit Murni Teguh memberikan pelayanan kepada pasien umum dan pasien yang menggunakan Badan Penyelenggaraan Jamian Sosial (BPJS) di rumah sakit. Unit perawatan covid19 terdiri dari 3 ruangan yang berbeda yaitu ada di gedung b lantai 3 dimana ruangan ini adalah ICU covid, kemudian ada di lantai 5 dan 6 dimana ruangan ini adalah unit rawap inap.

Petugas kesehatan di unit ICU terdiri dari dokter penanggung jawab, 19 perawat dan 1 kepala ruangan, serta ruangan ini dapat menampung sampai 10 pasien. Petugas kesehatan di unit rawat inap gedung lantai 5 terdiri dari dokter penanggung jawab, 39 perawat dan 1 kepala ruangan, serta ruangan ini dapat menampung sampai 60 pasien. Petugas kesehatan di unit rawat inap gedung lantai 6 terdiri dari dokter penanggung jawab, 22 perawat, dan 1 kepala ruangan, serta ruangan ini dapat menampung sampai 42 pasien. Dalam memberikan pelayanan kepada pasien, yayasan dan pimpinan rumah sakit selalu menekankan untuk memberikan pelayanan yang berkualitas sesuai dengan protokol kesehatan sebagai cara untuk memutus mata rantai penyebaran covid-19, karena menurut pimpinan hal tersebut diharapkan dapat menjadi cerminan kebaikan kepada orang lain yang akan menjadi kenangan sepanjang masa.

2) Perspektif tim manajerial PPI tentang program pencegahan dan pengendalian infeksi covid-19 di Rumah Sakit

Wawancara dilakukan dengan teknik indept interview terhadap partisipan berdasarkan pada beberapa pokok bahasan yaitu 1) Pengertian pencegahan dan pengendalian infeksi covid-19, 2) Tujuan dari pelaksanaan program pencegahan dan pengendalian infeksi covid-19, 3) Manfaat dari pelaksanaan program pencegahan dan pengendalian infeksi covid-19, 4) Pelaksanaan program 
pencegahan dan pengendalian infeksi covid-19, 5) Yang bertanggungjawab dalam pelaksanaan program pencegahan dan pengendalian infeksi covid-19, 6) Materi yang perlu dilaksanakan dalam program pencegahan dan pengendalian infeksi covid-19, 7) Hambatan dalam pelaksanaan program pencegahan dan pengendalian infeksi covid-19, 8) Harapan atas pelaksanaan program pencegahan dan pengendalian infeksi covid-19.

3) Pemeriksaan status kesehatan pada tenaga kesehatan terhadap infeksi covid-19 di Rumah Sakit

Berdasarkan hasil pemeriksaan kesehatan menggunakan Test PCR / Anti Gen pada tenaga kesehatan di rumah sakit kepada 7 orang tenaga kesehatan didapat hasil yaitu :

Tabel 3. Pemeriksaan Test PCR/ Anti Gen Pada tenaga Kesehatan Di Rumah Sakit

\begin{tabular}{llcc}
\hline No & PCR/ Anti Gen & Frekuensi & Persentase $\%$ \\
\hline 1 & Negative & 5 & $71.43 \%$ \\
\hline 2 & Positive & 2 & $28.57 \%$ \\
\hline & Jumlah & 7 & 100 \\
\hline
\end{tabular}

Berdasarkan hasil pemeriksaan vital sign pada tenaga kesehatan di rumah sakit kepada 7 orang tenaga kesehatan didapat hasil yaitu :

Tabel 4. Pemeriksaan Vital Sign Pada Tenaga Kesehatan Di Rumah Sakit

\begin{tabular}{clcc}
\hline No & Vital Sign & Frekuensi & Persentase \% \\
\hline 1 & Normal & 6 & 85.71 \\
\hline 2 & Tidak Normal & 1 & 14.29 \\
\hline & Jumlah & 7 & 100 \\
\hline
\end{tabular}

\subsubsection{Proses Action Research : Planning, Action, Observation dan Reflection}

Pelaksanaan action research pada penelitian ini adalah satu siklus tentang pengembangan program pencegahan dan pengendalian infeksi covid-19 dalam mempertahankan status kesehatan pada tenaga kesehatan di rumah sakit melalui tahapan planning, action, observation dan reflection. Kegiatan action research dilaksanakan selama 11 minggu dimulai dari 21 Juni sampai dengan 4 September 2021. Berikut penjelasan hasil kegiatan yang telah dilaksanakan sesuai tahapan.

1) Tahap Planning

Kegiatan pada tahap ini yaitu menyusun rencana aksi atau kegiatan yang kemudian dilaksanakan pada tahap penelitian berikutnya. Tahap planning telah dilaksanakan pada tanggal 21 Juni 2021. Tahap ini bertujuan untuk mengembangan program pencegahan dan pengendalian infeksi covid-19 dalam mempertahankan status kesehatan pada tenaga kesehatan di rumah sakit. Berdasarkan temuan pada tahap reconnaissance maka tahap ini direncanakan beberapa kegiatan demi tercapainya tujuan yang telah dirumuskan. Rencana yang telah disusun kemudian dijadikan panduan untuk membuat pengembangan program pencegahan dan pengendalian infeksi covid- 19 .

Rencana yang telah disusun pada tahap planning yaitu merencanakan pembentukan tim pelaksana program pencegahan dan pengendalian infeksi covid-19 yaitu tanggal 21 Juni 2021, pemberian materi tentang pencegahan dan pengendalian infeksi covid-19 serta pembuatan standar prosedur operasional (SPO) program pencegahan dan pengendalian infeksi covid-19 yaitu tanggal 23 Juni sampai dengan 17 Juli 2021, seminar dan sosialisasi SPO program pencegahan dan pengendalian infeksi covid-19 yaitu 21 sampai dengan 24 Juli 2021, rencana penerapan SPO dan observasi terhadap program pencegahan dan pengendalian infeksi covid-19 yaitu tanggal 26 Juli sampai dengan 28 Agustus 2021. Untuk tahap reflection direncanakan tanggal 30 Agustus sampai dengan 4 September 2021.

2) Tahap Action

Tahap action dilaksanakan pada tanggal 21 Juni sampai dengan 24 Agustus 2021. Terdapat lima kegiatan pada tahap ini yaitu pembentukan tim pelaksana program pencegahan dan pengendalian infeksi covid-19, pemberian seminar tentang pencegahan dan pengendalian infeksi covid-19, pembuatan SPO program pencegahan dan pengendalian infeksi covid-19, sosialisasi SPO pencegahan dan pengendalian infeksi covid-19, dan penerapan SPO program pencegahan dan pengendalian infeksi covid-19. 
3) Tahap Observation

Tahap observasi dilaksanakan pada saaat pelaksanaan program pencegahan dan pengendalian infeksi covid-19 berlangsung. Pemberi materi diobservasi oleh peneliti, dan direktur serta tim PPI rumah sakit juga terlibat dalam melakukan observasi kepada pemberi materi. Peneliti melakukan observasi terhadap tim PPI yang bertangung jawab didalam pelaksanaan program pencegahan dan pengendalian infeksi covid-19 di rumah sakit, dan juga peneliti mengobservasi partisipan tenaga kesehatan, serta dokumen program pencegahan dan pengendalian infeksi covid-19 tersebut.

4) Tahap Reflection

Tahap reflection dilakukan untuk menilai kemajuan, kelemahan, dan kendala atas pelaksanaan program pencegahan dan pengendalian infeksi covid-19 yang telah dilaksanakan. Pada tahap ini peneliti melakukan focus group discussion (FGD) pada kelompok manajerial PPI dan melakukan pemeriksaan kesehatan pada tenaga kesehatan untuk melihat status kesehatan setelah diterapkan standar prosedur operasional program pencegahan dan pengendalian infeksi covid-19. Pemeriksaan kesehatan pada tenaga kesehatan dilakukan pada tanggal 27 Agustus 2021, dan FGD dilakukan pada tanggal 1 september 2021. Selanjutnya peneliti melakukan analisa terhadap hasil status kesehatan dan FGD dilakukan pada tanggal 1 sampai dengan 4 September 2021.

Jumlah partisipan pada tenaga kesehatan tidak mengalami perubahan, jumlahnya tetap sama seperti awal pelaksanaan yaitu 7 orang. Untuk kegiatan FGD pada tim manajerial PPI jumlah partisipan yang hadir tidak semua, hanya 5 orang saja yang terdiri dari 1 laki-laki dan 4 perempuan. Tidak semua partisipan dapat hadir disebabkan karena adanya kesibukan kerja.

Tujuan kegiatan FGD tahap reflection untuk mengetahui atau menilai program pencegahan dan pengendalian infeksi covid-19 yang telah dilaksanakan. Terdapat lima tema yang diperoleh berdasarkan refleksi selama menerapkan program yaitu 1) Pengalaman dalam melaksanakan program pencegahan dan pengendalian infeksi covid-19, 2) Manfaat yang dirasakan setelah menerapkan pencegahan dan pengendalian infeksi covid-19, 3) Faktor pendukung dalam menerapkan program pencegahan dan pengendalian infeksi covid-19, 4) Faktor penghambat dalam melaksanakan program pencegahan dan pengendalian infeksi covid-19, dan 5) Harapan dalam menerapkan program pencegahan dan pengendalian infeksi covid-19.

\subsection{Out Put Pengembangan Program Pencegahan dan Pengendalian Infeksi Covid-19}

Penelitian ini mendapatkan output yaitu standar prosedur operasional program pencegahan dan pengendalian infeksi covid-19. Standar prosedur operasional telah disusun berdasarkan hasil rapat atau pertemuan antara tim manajerial PPI dan peneliti yang mengacu pada standar prosedur operasional yang ada di Rumah Sakit Murni Teguh Kota Medan yang dikombinasikan dengan konsep interpersonal teaching learning; coaching dan telah disesuaikan dengan kebutuhan serta keadaan rumah sakit.

Analisa dan hasil diskusi yang telah dilakukan oleh tim manajerial PPI dan peneliti terhadap pencegahan dan pengendalian infeksi covid-19 menghasilkan beberapa hal yang dapat dimasukkan kedalam SPO program pencegahan dan pengendalian infeksi covid-19 dan dapat diterapkan antara lain : 1) pencegahan dan pengendalian penyebaran covid-19, 2) penggunaan APD, 3) melepaskan APD, 4) penanganan pasien suspek, probable dan terkonfirmasi covid-19 di ruang rawat inap non isolasi dan transfer menuju ruang isolasi covid-19, 5) penempatan pasien suspek, probable dan yang terkonfirmasi covid-19, 6) pembersihan ruang isolasi covid-19, 7) pembersihan dan desinfeksi lingkungan rumah sakit di masa pandemic covid-19, 8) pemulangan jenazah suspek, kasus probable, dan konfirmasi covid-19, 9) penyuntikan vaksinasi covid-19, 10) early warning system, 11) training update. Pelaksanaan program pencegahan dan pengendalian infeksi covid-19 dilakukan selama 1 bulan yaitu di 3 unit : 1 unit ICU covid, dan 2 unit rawat inap isolasi covid.

\subsection{Outcome Pengembangan Program Pencegahan Dan Pengendalian Infeksi Covid-19}

Hasil penelitian terlihat dari status kesehatan dari tenaga kesehatan yaitu pemeriksaan test PCR/ Antigen dan vital sign. Proses penelitian action research tentang pengembangan program pencegahan dan pengendalian infeksi covid-19 berdampak dalam mempertahankan status 
kesehatan pada tenaga kesehatan. Dampak tersebut diketahui melalui pengumpulan data yang dilakukan dengan cara pemeriksaan status kesehatan : PCR/Anti gen dan vital sign. Hasil pengumpulan data yang telah dilakukan pada sebelum dan sesudah penerapan program pencegahan dan pengendalian infeksi covid-19 mengalami peningkatan. Nilai presentasi sebelum penerapan program pencegahan dan pengendalian infeksi covid-19 adalah $71.43 \%$ tenaga kesehatan yang negative, $28.57 \%$ tenaga kesehatan yang positive, dan $85.71 \%$ hasil vital sign tenaga kesehatan yang normal, $14.29 \%$ hasil vital sign tenaga kesehatan yang tidak normal. Setelah dilakukan penerapan program pencegahan dan pengendalian infeksi covid-19 didapatkan hasil $85.71 \%$ tenaga kesehatan yang negative, $14.29 \%$ tenaga kesehatan yang positive, dan $100 \%$ hasil vital sign tenaga kesehatan yang normal seluruhnya.

Tabel 5. Pemeriksaan Test PCR/ Anti Gen Setelah Penerapan Program Pencegahan Dan Pengendalian Infeksi Covid-19 Pada tenaga Kesehatan Di Rumah Sakit

\begin{tabular}{clcc}
\hline No & PCR/Anti Gen & Frekuensi & Persentase \% \\
\hline 1 & Negative & 6 & 85.71 \\
\hline 2 & Positive & 1 & 14.29 \\
\hline & Jumlah & 7 & 100 \\
\hline
\end{tabular}

Tabel 6. Pemeriksaan Vital Sign Setelah Penerapan Program Pencegahan Dan Pengendalian Infeksi Covid-19 Pada tenaga Kesehatan Di Rumah Sakit

\begin{tabular}{llcc}
\hline No & Vital Sign & Frekuensi & Persentase \% \\
\hline 1 & Normal & 7 & 100 \\
\hline 2 & Tidak Normal & - & - \\
\hline & Jumlah & 7 & 100 \\
\hline
\end{tabular}

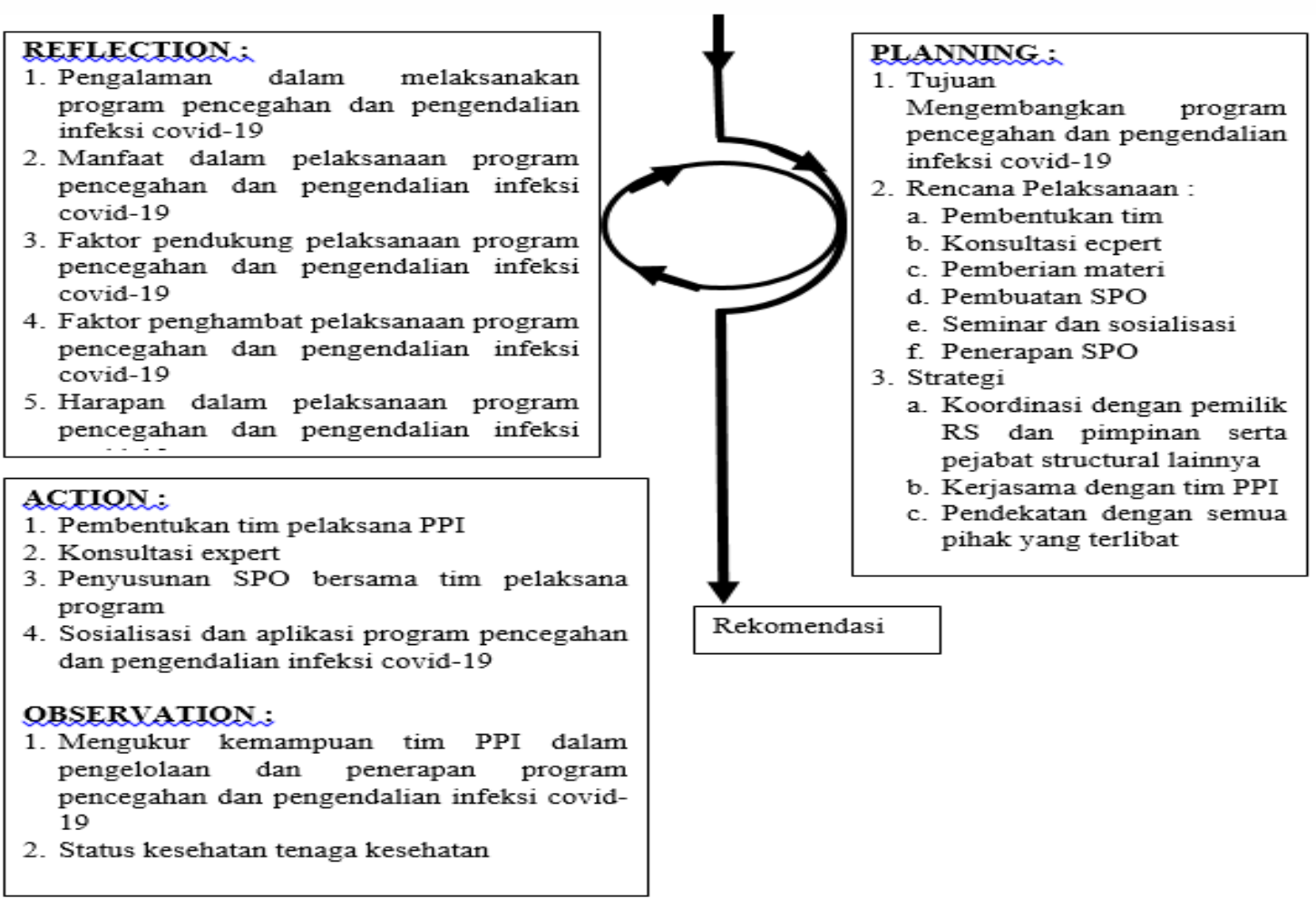

Skema 1 - Siklus action research pengembangan program pencegahan dan pengendalian infeksi covid-19 


\section{Pembahasan}

Hasil penelitian ini mendapatkan output yaitu standar prosedur operasional program pencegahan dan pengendalian infeksi covid-19, dan dari hasil pemeriksaan status kesehatan pada petugas kesehatan dari sebelum dan sesudah penerapan program pencegahan dan pengendalian infeksi covid-19 didapatkan hasil yaitu sebelum (PCR/Antigen: Negative 71.43\%, Positive: 28.57\%; Vital sign normal: 85.71\%, Tidak normal 14.29\%), dan sesudah (PCR/Antigen : Negative $85.71 \%$, Positive : $14.29 \%$; Vital sign normal : 100\%). Hal ini membuktikan bahwa terdapat pengaruh program pencegahan dan pengendalian infeksi Covid-19 dalam mempertahankan status kesehatan pada tenaga kesehatan di rumah sakit.Pedoman pencegahan dan pengendalian infeksi bertujuan untuk mewujudkan patient safety yang pada akhirnya akan berdampak pada peningkatan kualitas pelayanan [2].

Partisipasi aktif dari partisipan sangat mempengaruhi penelitian action research, sehingga apabila partisipan mengalami kendala atau halangan dalam menjalani kegiatan yang ditetapkan, maka kegiatan bisa jadi tertunda. Oleh karena itu beberapa kegiatan yang telah terjadwal dapat berubah karena situasi dan kondisi yang berhubungan dengan aktifitas partisipan dan harus dijadwal ulang. Situasi yang dapat menyebabkan perubahan jadwal antara lain banyaknya pekerjaan partisipan dalam melayani pasien, jumlah tenaga kesehatan yang terbatas sehingga mengharuskan partisipan memiliki beban kerja yang tinggi.

Kebutuhan pelayanan kesehatan akan mengalami peningkatan seiring dengan meningkatnya jumlah kasus [9], dan untuk meminimalkan risiko terjadinya paparan Covid-19 kepada petugas kesehatan dan non kesehatan, pasien dan pengunjung di fasilitas pelayanan kesehatan perlu diperhatikan prinsip pencegahan dan pengendalian risiko penularan sebagai berikut: 1) Menerapkan kewaspadaan isolasi untuk semua pasien, 2) Menerapkan pengendalian administrasi, 3) Melakukan pendidikan dan pelatihan. Tingginya resiko tenaga kesehatan yang terpapar Covid-19 bisa disebabkan oleh lamanya terpapar virus dan jumlah virus yang banyak sewaktu melakukan kontak dengan pasien [7]. Hal ini membuktikan bahwa sangat penting dalam melindungi tenaga kesehatan dari risiko infeksi Covid-19.

\section{Kesimpulan}

Penelitian ini membuktikan bahwa terdapat pengaruh program pencegahan dan pengendalian infeksi Covid-19 dalam mempertahankan status kesehatan pada tenaga kesehatan di rumah sakit. Saran kepada pimpinan rumah sakit untuk terus mengevaluasi program pencegahan dan pengendalian infeksi covid-19 sesuai dengan perkembangan dan situasi yang dihadapi.

\section{Referensi}

[1] Kemenkes RI. Pedoman pencegahan dan pengendalian coronavirus disease (covid19). Kementerian Kesehatan RI. 2020.

[2] Kemenkes RI. Pedoman pencegahan dan pengendalian infeksi di fasilitas pelayanan kesehatan. Peraturan Menteri Kesehatan Republik Indonesia No.27 Tahun 2017.

[3] Nathavitharana, R. R., Patel, P. K., Tierney, D. B., Mehrotra, P., Lederer, P. A., Davis, S., \& Nardell, E. Innovation and knowledge sharing can transform covid-19 infection prevention response. Journal of Hospital Medicine, 15 (5), 299-301. https://doi.org/10.12788/jhm.3439. 2020.

[4] Safrizal., Putra, D.A., Sofyan, S., \& Bimo. Pedoman umum menghadapi pandemi covid-19 bagi pemerintah daerah. Tim Kerja Kemendagri. 2020.

[5] Susilo, A., Rumende, C. M., Pitoyo, C. W., Santoso, W. D., Yulianti, M., Sinto, R., Cipto, R. (2020). Coronavirus disease 2019 : tinjauan literatur terkini coronavirus disease 2019 : review of current literatures. Jurnal Penyakit Dalam Indonesia, 7(1), 45-67. 2019.

[6] Sharma, S. K., Mudgal, S. K., Panda, P. K., Gupta, P., \& Agarwal, P. Covid-19: guidance outlines on infection prevention and control for health care workers. Indian Journal of Community Health , 32 (1), 9-16. 2020. 
[7] Tan, LF. Preventing the transmission of covid-19 amongst healthcare workers. Journal of Hospital Infection, 105 (2), 364-365. https://doi.org/10.1016/j. jhin.2020.04.008. 2020.

[8] Gupta, A., \& Kakkar, R. Managing a covid 19 patient at different health care and field level settings. Indian Journal of Community Health, 32 (2 Special Issue), 188-195. 2020.

[9] Setiati, S., \& Azwar, M. K. Covid-19 and Indonesia. Acta Med Indones-Indones J Intern Med, Vol 52 Number 1 Januari 2020. 